\title{
Reproductive biology of Kalanchoe laetivirens (Crassulaceae) in the edaphoclimatic conditions of Santa Catarina, Brazil
}

Biologia reprodutiva de Kalanchoe laetivirens (Crassulaceae) nas condições edafoclimáticas de Santa Catarina, Brasil

Biología reproductiva de Kalanchoe laetivirens (Crassulaceae) en las condiciones edafoclimáticas de Santa Catarina, Brasil

Received: 12/30/2020 | Reviewed: 01/08/2021 | Accept: 01/11/2021 | Published: 01/13/2021

Leonardo Norberto de Sousa Filho ORCID: https://orcid.org/0000-0002-6673-8214 Universidade Federal de Santa Catarina, Brazil E-mail: leo_nsf@hotmail.com Jean Bressan Albarello ORCID: https://orcid.org/0000-0001-8840-1893 Universidade Federal de Santa Catarina, Brazil E-mail: jeanalbarello@gmail.com

Mayara Martins Cardozo ORCID: https://orcid.org/0000-0001-8506-2785 Universidade Federal de Santa Catarina, Brazil E-mail: may.cardozo@icloud.com

Márcia Regina Faita

ORCID: https://orcid.org/0000-0003-1664-134X Universidade Federal de Santa Catarina, Brazil E-mail: marcia.faita@gmail.com

Cristina Magalhães Ribas dos Santos ORCID: https://orcid.org/0000-0002-9118-6730 Universidade Federal de Santa Catarina, Brazil E-mail: cristina.ribas@ufsc.br

\begin{abstract}
Crassulaceae of the Kalanchoe laetivirens species have ornamental potential, but are poorly studied, especially their reproductive biology and trophic resources made available to visitors. The aim of this study, therefore, was to characterize the reproductive system of $K$. laetivirens through analyses of floral morphology, trophic resources and floral visitors. Floral structures, pollen / egg ratio, in vitro pollen germination, pollen grain structure in scanning microscopy and the availability of trophic resources by the evaluation of potential and instant nectar were described. The survey of floral visitors was carried out, and the pollen and nectar collection frequencies were recorded. The results show that the species has tubular flowers, complete with tetramer calyx and corolla, eight epipetalous stamens and four pistils with pluriovulated ovaries. Based on pollen / ovule ratio, this species is optionally autogamous. Morphologically, the pollen grain is small, tricolporate and has radial symmetrywith in vitro germination facilitated in the presence of sucrose $(20 \%)$. Visitors mostly collected pollen with the highest frequency of visits at 9:30 am. The production of instant nectar had little variation between the evaluated times. The results are relevant to the understanding of the reproductive biology of Kalanchoe laetivirens and its relationship with floral visitors.
\end{abstract}

Keywords: Reproduction systems; Floral morphology; Floral resources; Pollen characteristics.

\section{Resumo}

As crassuláceas da espécie Kalanchoe laetivirens possuem potencial ornamental e são pouco estudadas, especialmente quanto a biologia reprodutiva e recursos tróficos disponibilizados aos visitantes. O objetivo deste estudo foi caracterizar o sistema reprodutivo de K. laetivirens através de análises da morfologia floral, recursos tróficos e visitantes florais. Foram descritas as estruturas florais, razão pólen/óvulo, germinação de pólen in vitro, estrutura do grão de pólen em microscopia de varredura e a disponibilidade de recursos tróficos pela avaliação do néctar potencial e instantâneo. Foi realizado o levantamento de visitantes florais e registradas as frequências de coleta de pólen e néctar. Os resultados demonstram que a espécie apresenta flores tubulosas, completas, com cálice e corola tetrâmeros, oito estames epipétalos e quatro pistilos com ovários pluriovulados. Pela razão pólen/óvulo, essa espécie é autógama facultativa. Morfologicamente, o grão de pólen é pequeno, tricolporado e apresenta simetria radial, com germinação in vitro facilitada na presença de sacarose $(20 \%)$. Os visitantes coletaram majoritariamente pólen, sendo a maior frequência de visitas às 9h:30mim. A produção de néctar instantâneo teve pouca variação entre os horários avaliados. 
Os resultados são relevantes para o entendimento da biologia reprodutiva de Kalanchoe laetivirense sua relação com os visitantes florais.

Palavras-chave: Sistemas de reprodução; Morfologia floral; Recursos florais; Características do pólen.

\section{Resumen}

Las crasuláceas de la especie Kalanchoe laetivirens tienen potencial ornamental pero están poco estudiadas, especialmente la biología reproductiva y los recursos tróficos puestos a disposición de los visitantes florales. El objetivo del estudio fue caracterizar el sistema reproductivo de $K$. laetivirens mediante análisis de morfología floral, recursos tróficos y visitantes florales. Se describieron las estructuras florales, relación polen / huevo, germinación de polen in vitro, estructura de grano de polen en microscopía de barrido y disponibilidad de recursos tróficos mediante la evaluación de néctar y potencial instantáneo. Se realizó una evaluación de visitantes florales y se registraron las frecuencias de recolección de polen y néctar. Los resultados muestran que la especie tiene flores tubulares, con cáliz y corola tetrámeros, ocho estambres epipetales y cuatro pistilos con ovarios pluriovulados. Por la proporción del polen / óvulo, esta especie es autógama opcional. Morfológicamente, el grano de polen es pequeño, tricolporado y tiene simetría radial, con germinación in vitro facilitada por la presencia de sacarosa (20\%). La mayoría de los visitantes recolectaron polen, con la mayor frecuencia de visitas a las 9:30 am. La producción de néctar instantáneo poco varió en los tiempos evaluados. Los resultados son relevantes para la comprensión de la biología reproductiva de Kalanchoe laetivirens y su relación con los visitantes florales.

Palabras clave: Sistemas de reproducción; Morfología floral; Recursos florales; Características del polen.

\section{Introduction}

The Crassulaceae family is represented by vegetables, such as Kalanchoe laetivirens Descoings (1997), succulent plants originating in tropical areas, mainly in Africa. Some species of this genus are widely distributed in horticulture, with $K$. pinnata Lam and K. daigremontiana being the best known (Milad, El-Ahmady \& Singab 2014).

Kalanchoe phytochemicals are widely described, but the most important highlight is in the area of plant physiology owingto the acidic metabolism of crassulaceae (Garcia, 1998; Milad, El-Ahmady \& Singab 2014). However, research on the reproductive system of these plants is scarce, in particular their floral biology, production of trophic resources and interactions with possible floral visitors.

Plants have floral organs with morphological, phenological and physiological peculiarities that influence the reproductive process, with pollination being dependent on animals as the most efficient method of distribution (Rech, Agostini, Oliveira \& Machado, 2014). The convergent adaptations between plants and animals, specifically floral visitors, or between plants and abiotic factors (water, wind) culminated in the emergence of many pollination syndromes (Van der Pijl, 1961). Among the strategies developed by plants are adaptations that stimulate visitors' senses, such as color, odor, or flower shape (Goulson, 1999; Andersson, Nilsson, Groth \& Bergström., 2002), and the availability of resources, such as nectar, pollen and oils (Andrada, Valle, Paoloni, Gallez, \& Lamberto, 2004; Eguiarte, Del Rio \& Arita, 1987; Machado \& Lopes, 1998). These strategies directly influence pollination efficiency.

To close the gap in the understudied reproductive system of $K$. laetivirens, the present study focused on its reproductive processes in the edaphoclimatic conditions of Santa Catarina, Brazil, through the prism of its morphology, resources and floral visitors.

\section{Methodology}

\subsection{Study sites and plant material}

Field evaluations were carried out on days with stable weather (average temperature of $19.9^{\circ} \mathrm{C}$, relative humidity of 77.16\% and average wind speed of $43 \mathrm{~km} / \mathrm{h}$ ), in the city of Paulo Lopes (- 27.966491 S, - 48.660037 W), Santa Catarina, Brazil. The local climate, according to the Köppen classification, is Cfa, Humid Subtropical Climate (Mesothermal). The analyses were performed at the Agricultural Entomology Laboratory of the Federal University of Santa Catarina (LabEntoUFSC) in Florianópolis. 
The study was carried out with clones of a matrix plant of $K$. laetivirens identified by the botanical key of Shaw (2008) based on morphological characteristics and in studies of Smith (2020). Another reference in the identification of the species was a registered exsiccate $\left(\mathrm{n}^{\circ}\right.$ 532) deposited on July 3, 1979 at the Herbarium Jardim Botânico of Rio de Janeiro.

\subsection{Floral morphology of stamens and pistils}

The morphological characterization of the flowers and the inflorescence of $K$. laetivirens were supported by the descriptions proposed by Gonçalves (2011) and Souza, Flores and Lorenzi (2013). Pollen grains were evaluated by scanning electron microscopy and described following the terminology standardized by Punt et al. (2007). Finally, measurements of stamens and pistils were performed with the aid of a caliper, using five flowers in balloon stage (adapted from Cortinóz et al., 2008).

\subsection{Flowering scale}

The classification of the flower's development phases was adapted to the initial proposal of criteria by Ducroquet and Hickel (1991), using the denominations shown in Table 1.

Table 1. Developmental stages of Kalanchoe laetivirens flowers, adapted according to the criteria proposed by Ducroquet and Hickel (1991).
Stadium

\section{Criterion}

\section{A}

$\mathrm{B} 1$ - B2

$\mathrm{C}$

D1

D2- D8

E

F1

F2

F3

G1 - G3
Dormant buds at multiple ends of the inflorescence

Beginning of flower bud development

Sepals start to move away

Appearance of petals

Development and expansion of flower bud in bloom

Balloon flower stadium

Open flower with pistils and open stamens (closed pollen bags)

Flower in full pollen release

Flower with empty pollen bags and stigma degeneration

Flower senescence

Source: Adaptation of Ducroquet and Hickel (1991).

\subsection{The receptivity of stigma and the viability of pollen grains}

The receptivity of the stigma was evaluated based on Dafni (1992), through the release of $\mathrm{O}_{2}$ (bubbling) in the reaction of hydrogen peroxide $\left(\mathrm{H}_{2} \mathrm{O}_{2}, 10\right.$ volumes), with the papillae of the stigma of the pistils of three flowers in stages $\mathrm{E}$, F1, F2 and F3 collected at the same time. In the event of bubbling, observed under stereomicroscopy (Feldmann Wild Lentz, 
FWL $-150,100 x), 25 \%$ receptivity was attributed to each of the four stigmas of each flower, generating a receptivity of 0 $100 \%$ per flower.

To assess pollen viability, the colorimetric method was used according to the methodology proposed by Dafni (1992). The anthers of three flowers in stages E, F1, F2 and F3 were rubbed lightly over slides; afterwards, $2 \mu \mathrm{L}$ of acetic carmine were added. Then, the material was covered with a cover slip, and after five minutes, the percentage of pollen grains stained was evaluated with the aid of an optical microscope (Studarlab 400x). In the case of closed anthers, it was necessary to leave them in Petri dishes for 24 hours at room temperature for dehiscence to occur.

\subsection{Estimation of the number of pollen grains and egg count}

Four anthers of five flowers in balloon (E) stage were randomly collected, and diluted in $0.5 \mathrm{~mL}$ of $85 \%$ lactic acid in $1.5 \mathrm{~mL}$ microtubes. Two $1.5 \mu \mathrm{L}$ aliquots of each microtube were pipetted in a Neubauer Chamber and observed under an optical microscope (Studarlab400x) to count pollen grains. An average of pollen grains from the aliquots (X) was obtained, and the total number of pollen grains for the four anthers was estimated as $\mathrm{N}=\mathrm{X} * 500 / 1.5 * 1 / 4(\mathrm{~N}=$ number of grains of pollen) of the same flower. (Albuquerque Junior, Denardi, Dantas \& Nodari, 2010; Kearns \& Inouye, 1993).

For the egg count, the pistils of five flowers in balloon stage (E) were placed on the sticky face of a transparent adhesive tape fixed on a glass slide. The ovaries were opened with the aid of histological needles, and the eggs were gently extended on the tape, facilitating their counting with a stereomicroscope (Feldmann Wild Lentz, FWL - 150, $100 \mathrm{x}$ ).

The pollen / egg (P / O) ratio was obtained according to Cruden (1977). The fraction between the average number of pollen grains and the number of eggs per flower made it possible to infer the type of reproductive system.

\subsection{In vitro germination of pollen grains}

Pollen grains of 12 F2 flowers (three flowers per treatment) were distributed directly from the anthers on the growth medium ( $1 \mathrm{~g}$ agar $/ 100 \mathrm{~mL}$ of distilled water; $40 \mathrm{mg} . \mathrm{L}^{-1}$ of boric acid) deposited on Petri dishes $(10 \mathrm{~mL})$. Four different sucrose concentrations of 0,10,20 and 40\% were established, totaling four treatments, with five replicates each (adapted from Nunes et al., 2001). Subsequently, the Petri dishes were kept in an incubator with biochemical oxygen demand (BOD Electrolab) at $25^{\circ} \mathrm{C}$. Germination was evaluated under an optical microscope (Studarlab $100 \mathrm{x}$ ) at 1, 4 and 8 hours after distribution of pollen grains in the growth medium.

\subsection{Scanning electron microscopy (SEM)}

Samples of androecium and gynoecium of flowers in F2 were collected and immediately transferred to polypropylene tubes $(1.5 \mathrm{~mL})$ containing Karnovsky's Fixative (2.5\% glutaraldehyde, $2 \%$ formaldehyde in $0.1 \mathrm{M}$ sodium cacodylate buffer, $\mathrm{pH}$ 7.2). The samples remained submerged in the fixative and were refrigerated $\left(4^{\circ} \mathrm{C}\right)$ for $48 \mathrm{~h}$, followed by washing in $0.1 \mathrm{M}$ cacodylate buffer. Preparation of the samples for observation in SEM followed the standard dehydration protocol in increasing series of ethyl alcohol and distilled water (70 to 100\%) and drying with HMDS (Hexamethyldisilazane). Subsequently, the samples were assembled in stubs with double-sided carbon tape and subjected to metallization in a gold sputtering machine (modelEM SCD 500 / LEICA). The analyses were performed in a scanning electron microscope (JEOL JSM-6390LV), with an electron acceleration voltage of $10 \mathrm{kV}$, and the images were captured digitally by the JEOL / EO1.0 program, using equipment provided by the Central Laboratory of Electron Microscopy (LCME -UFSC). 


\subsection{Floral visitors}

The survey of floral visitors was carried out using the methods of Benevides, Gaglianone and Hoffmann (2009) and Polatto and Alves Junior (2008) with modifications. The evaluations were carried out from 6:30 am to 6:30 pm, considering a radius of $2 \mathrm{~m}$ between the plants. Floral visitors were determined through naturalistic observations lasting $10 \mathrm{~min}$ each hour, totaling four hours of observations on September 15 and 22, 2019. Visits were characterized as the visitor's permanence in the inflorescence from arrival to departure, regardless of the number of flowers visited. The floral visitor's behavior regarding the collection of nectar or pollen was also evaluated, considering only the first co lection per visit, given the difficulty of accounting for multiple collections from different visitors. To avoid interference with the number of visitors, specimens were not collected for identification.

\subsection{Instant and potential nectar}

Based on the methodology proposed by Dafni (1992), the volume was established by the nectar column, as measured with a caliper, in microcapillary tubes of $50 \mu \mathrm{L}$ as $\mathrm{VN}=(\mathrm{CN}$ x VM) / CM, where VN is the nectar volume $(\mu \mathrm{L}), \mathrm{CN}$ is the length of the nectar column in the capillary $(\mathrm{mm}), \mathrm{VM}$ is the standard volume of capillaries $(50 \mu \mathrm{L})$, and $\mathrm{CM}$ is capillary size $(\mathrm{mm})$.

The concentration of sugars in the nectar was measured in Brix degrees with a portable Bellingham \& Stanley refractometer scaled from 0 to $50^{\circ}$. To evaluate the potential nectar, 10 flowers were bagged at the F2 stage (flower in full release of pollen) for 12 hours between September 21 and 22, 2019. The instant nectar was evaluated in 20 F2 flowers at 8:30 am and 1:30pm on the 15th and 22nd of September 2019, without bagging the flowers, resulting in an average Brix ${ }^{\circ}$ and volume for each hour.

\section{10 Statistical analysis}

The data collected in relation to pistil and stigma morphometry and pollen grain germination were subjected to parametric analysis of variance and Tukey test $(p=0.05)$ to compare the averages in $R$ software.

\section{Results}

The flowers of Kalanchoe laetivirens have a green to rosacea color (Figure 1A), pedicellated, without hypanthium, complete, actinomorphic and have a cyclic arrangement of the floral pieces. In addition, they are tubular, tetrameres, dichlamydeous, heteroclamids, gamosepalous and gamopetalouswith valve prefloration (Figure 1B). The androecium was classified as diplostemonous, isodynamic, epipetalous, with stamens included up to balloon stage, basifixed anthers that have longitudinal dehiscence and powdery dispersion of pollen grains (Figure 1C). The gynoecium isapocarpous, tetracarpellar and unilocular (Figure 1D), parietal placentation, semi-infertile, numerous ovules (Figure 1E) with terminal insertion of the stylet and undivided stigma. The nectary is located between the stamens and carpels. The flowers are collected in cymose-type inflorescences called pleiochasium and, under the environmental conditions of this study, did not form seeds. 
Figure 1. Kalanchoe laetivirens. A - Detail of floral pieces showing sepals (Sep), petals (Pet), androecium composed of fillet (Fi) and anthers (An) and gynoecium where it is possible to view the ovary (Ov), stylus (Stl) and stigma (Stg). B - Tubular shape of the gamosepalous and gamopetalous flower. C. Opening of anthers (An) and dispersion of pollen grain mass (Mgp). D. Cross section of the ovary showing the nectaries $(\mathrm{Nec})$, the ovarian wall $(\mathrm{Ow})$, the ovarian lobules $(\mathrm{Ol})$, the eggs $(\mathrm{Eg})$, the ovarian septum (Osep) and the styling region (Stl-r). E. Longitudinal section of the ovary showing the ovarian parenchyma (Opr) and the locular region (Lo-r).

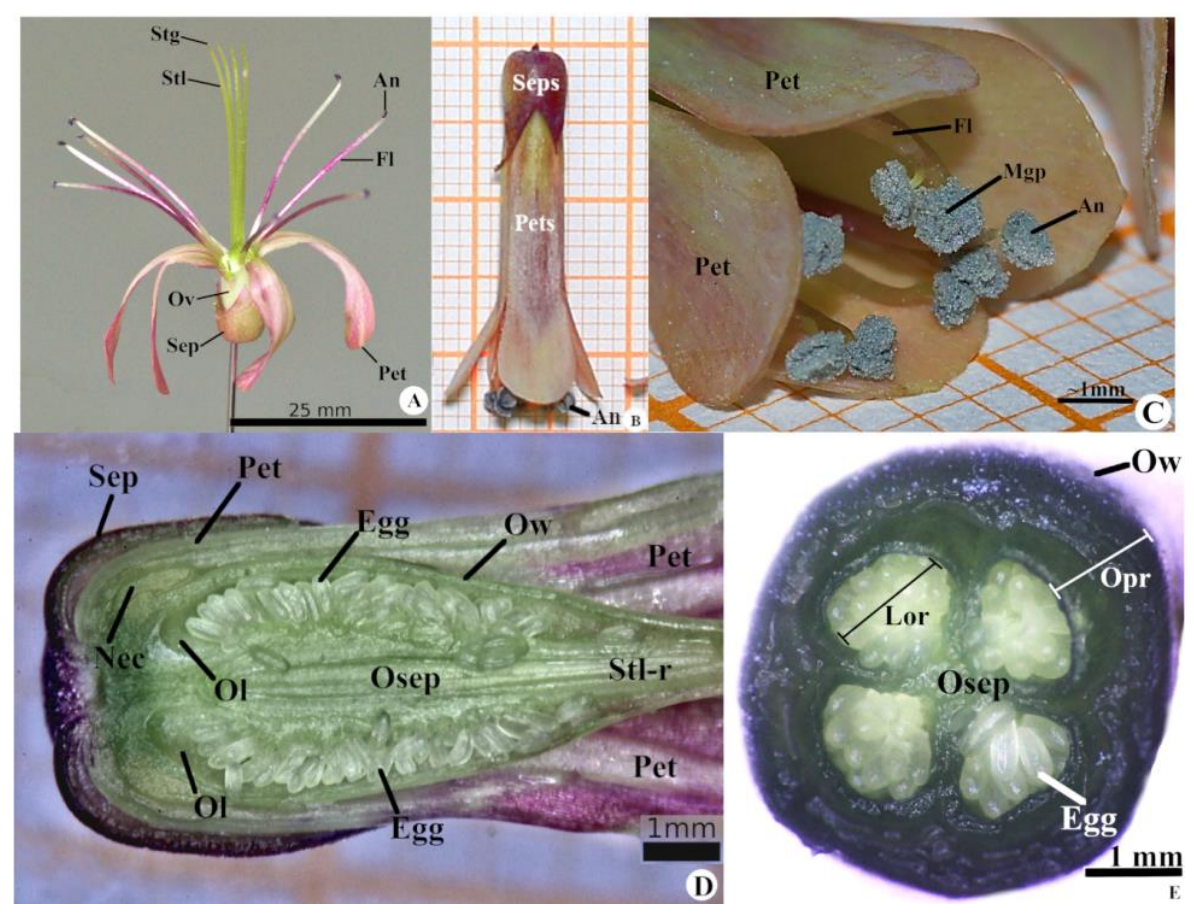

Source: Authors (2019).

In the flowering scale, seven stages of development were observed (Figure 2) according to morphological differences, sizes and colorations. In morphometry, the stamens presented an average size of $16.03 \mathrm{~mm}$ and the pistils $15.71 \mathrm{~mm}$, with no statistical differences between their sizes. 
Figure 2. Kalanchoe laetivirens flowering scale, where it is possible to identify the stages of flower development, from dormant buds (A) to complete senescence (G3), adapted according to criteria proposed by Ducroquet and Hickel (1991) and described in Table 1.

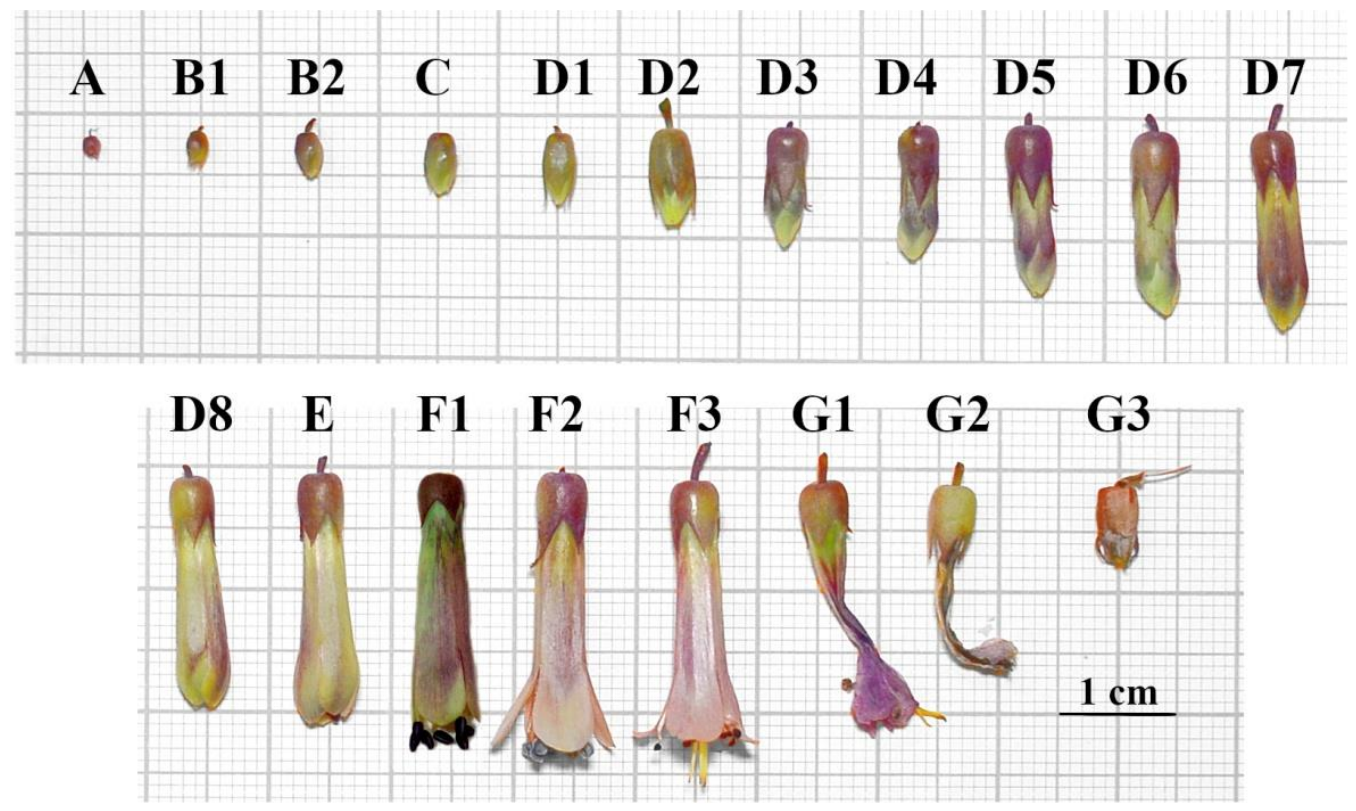

Source: Authors (2019).

Analysis of the scanning photomicrographs indicated that the pollen grains of $K$. laetivirens have a reduced size (10 $25 \mu \mathrm{m}$ ), are isopolar, tricolporate, prolatespheroidal and radially symmetrical. It was possible to distinguish the nectaries at the base of the carpels (Figure 3A) and to confirm the longitudinal dehiscence of the anthers (Figure 3B), as well as highlight the agglomeration of the pollen grains enabling characterization of their dispersion form (Figure 3C) asstriated-corrugated tectum (Figure 3D) and ornamentation classified as "Sedum hispanicum - type" according to Qaiser, Perveen and Sarwar (2015). 
Figure 3. Details of Kalanchoe laetivirens in scanning electron microscopy. A - Nectaries (Nec) at the base of the ovary (Bov) and the ovarian septum region (Osr). B - Longitudinal dehiscence of the anther (An), the stoma (St) and the Thecas (Tec). C Pollen grain mass (Mpg) and pollen grains (Pg). D - Detail of pollen grain furrows (Pgf) and exine ornamentation (Eo).
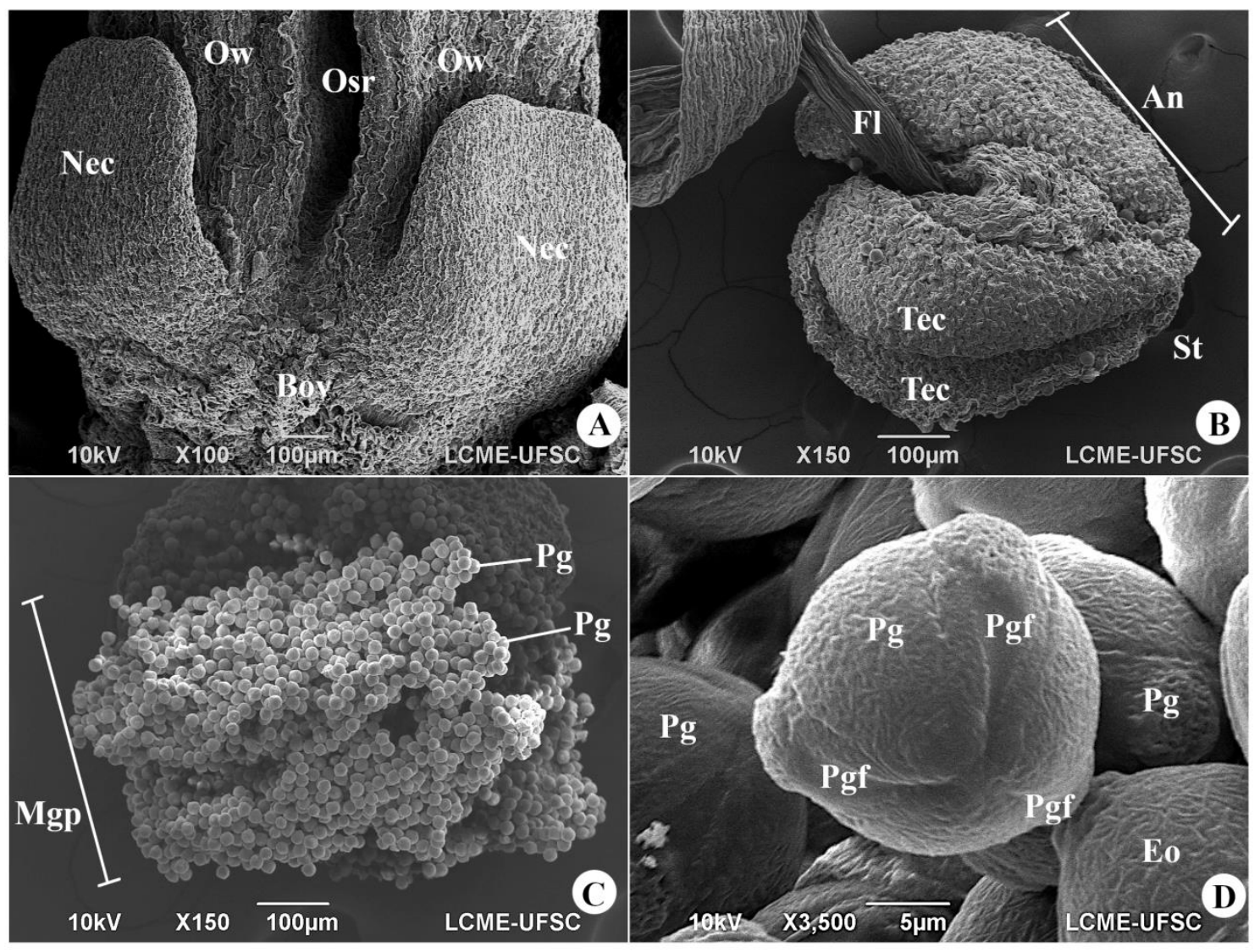

Source: Authors (2019).

Flowers of $K$. laetivirens at balloon stage (E) were estimated to produce an average of $74,116.00$ pollen grains $( \pm$ $3030.0)$ and 337.0 eggs $( \pm 5.0)$, which amounts to 219.93 pollen grains for each egg. The colorimetric test showed that pollen collected between stages E and F2 (Figure 4) was viable and that the maximum receptivity of the stigma occurs in conjunction with the dehiscence of the anther and the release of viable pollen in stage F2. 
Figure 4. Representation of stigma receptivity and the viability of Kalanchoe laetivirens pollen at different phenological stages of flowering. E - Balloon stadium; F1 - Open flower with pistils and open stamens (closed pollen bags); F2 - Flower in full release of pollen; F3 - Flower with empty pollen bags and stigma degeneration).

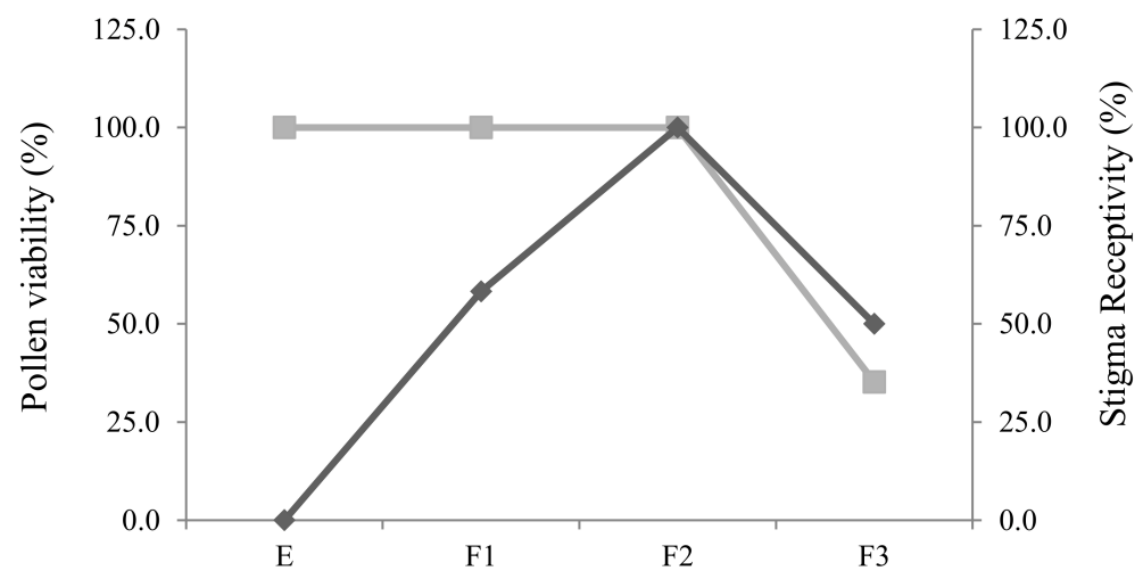

Phenological flowering stage

- Pollen viability $\quad$ Stigma Receptivity

Source: Authors (2019).

Pollen tube emission occurred within 8 hours, regardless of the treatment used. Pollen germination in vitro was affected by the concentration of sugar in the growth medium during the evaluated periods, except for pollen submitted to a concentration of $20 \%$ sucrose, the germination of which was above $90 \%$ in the first hour of evaluation and remained constant for all periods evaluated (Table 2). Irrespective of the presence of sugar, it should be noted that more than half of the pollen grains started to germinate in the first hour of evaluation.

Table 2. Germination of Kalanchoe laetivirens pollen grains evaluated after $1 \mathrm{~h}, 4 \mathrm{~h}$ and $8 \mathrm{~h}$, maintained in growth media with different concentrations of sucrose and boric acid $\left(40 \mathrm{mg} \cdot \mathrm{L}^{-1}\right)$ in the chamber with biochemical oxygen demand at $25^{\circ} \mathrm{C}$.

Average pollen germination for different sucrose concentrations

\begin{tabular}{ccccc} 
Evaluation times & $0 \%$ & $10 \%$ & $20 \%$ & $40 \%$ \\
\cline { 2 - 4 } 1 hour & $50.53 \mathrm{~b} \mathrm{C}$ & $73.11 \mathrm{c} \mathrm{B}$ & $91.70 \mathrm{a} \mathrm{A}$ & $67.26 \mathrm{c} \mathrm{B}$ \\
& $87.32 \mathrm{a} \mathrm{A}$ & $87.50 \mathrm{~b} \mathrm{~A}$ & $94.34 \mathrm{a} \mathrm{A}$ & $77.46 \mathrm{~b} \mathrm{~B}$ \\
4 hours & $92.12 \mathrm{a} \mathrm{A}$ & $95.97 \mathrm{a} \mathrm{A}$ & $95.77 \mathrm{a} \mathrm{A}$ & $85.16 \mathrm{a} \mathrm{B}$ \\
\hline
\end{tabular}

Means followed by distinct lowercase letters in rows, or uppercase letters in columns, differ significantly from each other by the Tukey test $(\mathrm{p} \leq 0.05)$, presenting a $\mathrm{CV}=5.09 \%$.

Source: Authors (2019).

In the average evaluation of floral visitors, approximately 35 visitors per day were recorded. Possibly, all were hymenopterans, of which $72.34 \%$ collected pollen and only $27.66 \%$ searched for nectar, with the highest frequency of visits at 9:30 am (Fig. 5). The potential nectar volume was $17.33 \mu \mathrm{L}( \pm 7.33 \mu \mathrm{L})$, and the average sucrose concentration was $9.24{ }^{\circ}$ Brix 
$\left( \pm 2.25^{\circ}\right.$ Brix), whereas for instant nectar, it ranged between 9.14 and $7.1 \mu \mathrm{L}$ and 13.36 and12.98 ${ }^{\circ}$ Brix (Figure 5) over the evaluation period.

Figure 5. Average number of floral visitors, volume $(\mu \mathrm{L})$ and sugar concentration $\left({ }^{\circ}\right.$ Brix) in the instant nectar of Kalanchoe laetivirens, as evaluated on different observation days in September 2019.

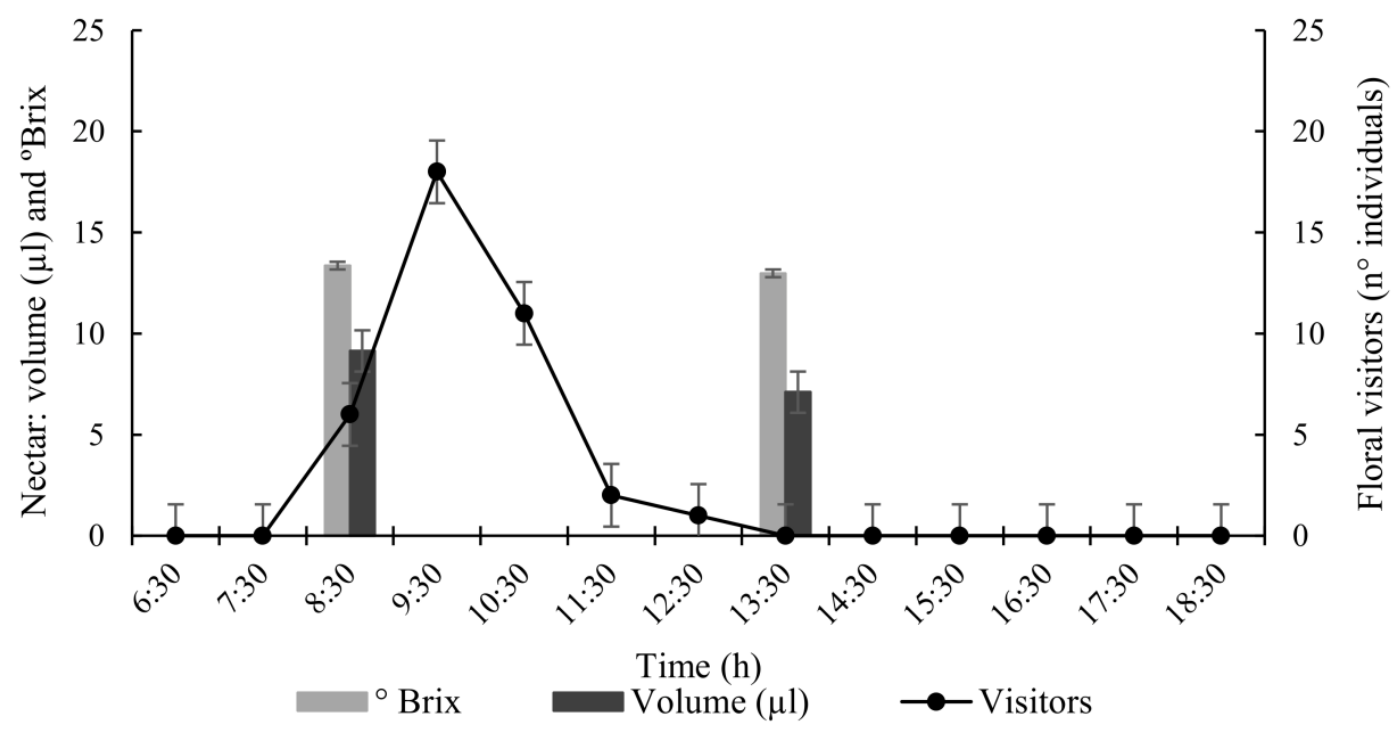

Source: Authors (2019).

\section{Discussion}

The morphological characteristics observed for the floral structures of $K$. laetivirens are those established by Milad, El-Ahmady and Singab (2014), and they are essential in the botanical identification of the species and in the construction of the flowering scale. Characterization of the flowers helps in the understanding of their morpho-functionality, consequently providing phylogenetic clues to the adaptations to which the plant organs were subjected throughout evolution (Oliveira, 1991). They can also help predict floral visitors and possible pollinators for the species, according to the interactions of the known pollination syndromes, which, in some cases, are extremely specialized, defined and well synchronized (Alves-dosSantos, Silva, Pinheiro \& Kleinert, 2016).

Flowers are one of the consumer products in the ornamental plant market, standing out as an economic activity that generates employment and income for micro and small producers across the country, with a significant participation of rural female labor (Junqueira \& Peetz,., 2014). In addition, knowledge of floral biology, together with the reproductive mechanisms of plant species, is essential for the establishment of plant breeding programs, allowing selection of the most appropriate technique for use (Allard, 1971). The establishment of breeding techniques for ornamental species in Brazil is a priority strategy for the development of this important sector of the economy (Cardoso, 2013).

The pollen grains of $K$. laetivirens fit the general pollen morphology of crassulaceae, as described by Qaiser, Perveen and Sarwar (2015) whose compendium of characteristics facilitates the distinction of pollen types by genera, given the heterogeneity between them. P/O ratio and the same size of the stamens and pistils observed in the evaluated flowers indicate that the specie can be classified as facultative and homomorphic autogamous, respectively (Cruden, 1977; Karasawa, 2009).

The flowers of $K$. laetivirens have characteristics similar to those of angiosperms with the capability of selfpollination since they present homogamy with viable pollen release just when the stigma is receptive (Rashid \& Singh, 2000). Aligned with the lack of physiological and morphological characteristics, such as heterogamyand heteromorphism, the 
abundance of pollen in longitudinal dehiscence anthers favors self-pollination (Costa, Krupek \& Krawczyk, 2015)

The germination of pollen grains in vitro was greater than $50 \%$ in the first hour of evaluation, regardless of the concentration of sugars in the culture medium, ensuring their viability. The germinative behavior of pollen grains depends on the osmotic balance between them and the culture medium, which is related to the carbohydrate source for the growth of the pollen tube (Stanley \& Linskens, 1974), in this case, facilitated by the concentration of $20 \%$ sugar. Additionally, the results obtained on the pollen aspects of $K$. laetivirens indicate that this species produces viable pollen and in large quantities with conditions conducive to the formation of seeds. It is noteworthy that pollen is not nutrition-intensive since they can be germinated in vitro in all concentrations of growth media evaluated.

Seed formation was not observed in the evaluated plants. It is possible that this occurred because of the selfincompatibility of the specimens used, considering that they were clones, which can be confirmed in future controlled pollination tests. Some species of Kalanchoe have the defective LEC1 gene, which prevents the formation of viable seeds; thus, they reproduce asexually by the formation of seedlings in the margins of the leaf blade, all coordinated by regulators of organogenesis and embryogenesis (Garcês et al., 2007). It is possible that $K$. laetivirens was a carrier of this gene, considering that the emission of seedlings was observed in the leaf blade, as previously described.

Visitors may prefer pollen over nectar by the ease of collection since it is a source exposed in these flowers,decreasing the energy cost of foraging (Rech, Agostini, Oliveira, \& Machado, 2014). It is also possible that the composition of the nectar of this plant has selectivity over the collectors (Adler, 2000). In addition, the local flora influences the dynamics of visits. For example, the collections of nectar or pollen made by Apis mellifera L. are correlated with the sources of food available throughout the different seasons (Malerbo-Souza \& Silva 2011).

The average values for the volume of potential and instantaneous nectar of $K$. laetivirens are similar to those of Echeveria gibbiflora (Parra, Vargas \& Eguiarte, 1993); however, the average sugar concentration ( ${ }^{\circ}$ Brix) found was three to five times lower than that in this species or in the nectar of $K$. daigremontiana (Herrera \& Nassar 2009). The volume of nectar is related to pollination syndrome. The ideal volume is one which attracts visitors, but does not satisfy them in a single flower, thus expanding visitation and, hence, the probability of cross-pollination (Wolf, 2006).

The composition of the nectar and the available quantity of this resource affect the dynamics of floral visits, even if foraging occurs in less favorable conditions (Polatto, Chaud-Netto \& Alves-Junior, 2014). Thus, environmental conditions are extremely important in the frequency of visits throughout the day, as they interfere with the ecophysiology of the plant, altering the production of resources such as nectar (Silva, Dutra, Nucci \& Polatto, 2013). Environment is also an influence, for example, the thermoregulation of insects and, consequently, their flight activity, depending on body sizes (Teixeira \& Campos, 2005). Therefore, both environmental conditions and resources favored visitation at 9:30 am within the diversity of visitors which frequented the flowers, similar to that reported by Pegoraro and Neto (2005).

From the results obtained, the sexual reproduction of $K$. laetivirens is a wasted energy investment for the survival of the species since seeds are not formed. Despite this, it is evident that its flowers are an important source of food (pollen and nectar) for visitors. This reproductive pathway proved to be only slightly viable for $K$. daigremontiana and $K$. pinnata, which, although producing seeds, have a low germination rate, opting instead for vegetative propagation (Herrera \& Nassar, 2009; Leon, Herrera \& Guevara, 2016). Such vegetative capacity is significant in the genus Kalanchoe, but both reproductive pathways, sexual and asexual, guaranteed the geographical expansion of these vegetables, even in places with inhospitable conditions (Allorge-Boiteaij, 1996).

\section{Conclusion}

The floral biology of Kalanchoe laetivirens is morphologically complex, but does not have functionality for 
reproductive purposes under the conditions of this study, and further evaluations are necessary to determine the causes deficit in the formation of seeds. However, the capacity of these plants to provide trophic resources to their floral visitors in the environments in which they inhabit stands out.

\section{Acknowledgments}

We are grateful to the Agricultural Entomology Laboratory (LabEnto -UFSC) for providing equipment and physical space to carry out the evaluations of this work, as well as to the Central Laboratory of Electronic Microscopy (LCME-UFSC) for availability and support in our scanning electron microscopy analyses. The authors would also like to thank the Coordination for the Improvement of Higher Education Personnel (CAPES) for granting grants to MMC and MRF.

\section{References}

Adler, L. S. (2000). The ecological significance of toxic nectar. Oikos, 91(3), 409-420. https://doi.org/10.1034/j.1600-0706.2000.910301.x

Albuquerque Junior, C. L. D., Denardi, F., Dantas, A. C. D. M., \& Nodari, R. O. (2010). Número de anteras por flor, grãos de pólen por antera e capacidade germinativa do pólen de diferentes cultivares de macieiras. Revista Brasileira de Fruticultura, 32(4), 1255-1260. https://doi.org/10.1590/S010029452010005000129

Allard, R. W. (1971). Sistemas reprodutivos e métodos de melhoramento de plantas. Princípios do melhoramento genético de plantas, 25-40.

Allorge-Boiteaij, L. (1996). Madagascar centre de speciation et d'origine du genre Kalanchoe (Crassulaceae). Biogéographie de Madagascar, 137-145. http://www.documentation.ird.fr/hor/fdi:010008454

Alves-dos-Santos, I., Silva, C. I. D., Pinheiro, M., \& Kleinert, A. D. M. P. (2016). Quando um visitante floral é um polinizador? Rodriguésia, 67(2), 295-307. https://doi.org/10.1590/2175-7860201667202

Andrada, A. C., Valle, A. L. D. A., Paoloni, P. A. B. L. O., Gallez, L., \& Lamberto, S. (2004). Pollen and nectar sources used by honeybee colonies pollinating sunflower (Helianthus annuus) in the Colorado River Valley, Argentina. Boletín de la Sociedad Argentina de Botánica, 39. http://digital.cic.gba.gob.ar/handle/11746/6567

Andersson, S., Nilsson, L. A., Groth, I., \& Bergström, G. (2002). Floral scents in butterfly-pollinated plants: possible convergence in chemical composition. Botanical Journal of the Linnean Society, 140(2), 129-153. https://doi.org/10.1046/j.1095-335 8339.2002.00068.x

Benevides, C. R., Gaglianone, M. C., \& Hoffmann, M. (2009). Visitantes florais do maracujá-amarelo (Passiflora edulis f. flavicarpa Deg. Passifloraceae) em áreas de cultivo com diferentes proximidades a fragmentos florestais na região Norte Fluminense, RJ. Revista Brasileira de Entomologia, 53(3), 415-421. https://doi.org/10.1590/S0085-56262009000300016

Cardoso, J. C. (2013). Melhoramento de espécies ornamentais como estratégia para o desenvolvimento e autossuficiência do setor. Horticultura Brasileira, 31(1), 171-171. https://doi.org/10.1590/S0102-05362013000100028

Cortinóz, J., Ilha, P., Rodrigues, P., \& Diniz, S. (2008). Heterostilia e deposição diferencial de pólen sobre o polinizador em Psychotria nuda (Rubiaceae). Projetos oriantados, 4, 1-3. http://www.ecologia.ib.usp.br/curso/2008/pdf/O_04_01.pdf

Costa, C. C. F., Krupek, R. A., \& Krawczyk, A. C. D. D. B. (2016). Diversidade de visitantes florais e biologia reprodutiva do Araçá (Psidium cattleianum Sabine) em fragmento de mata e área urbana. Títulos não-correntes, 29(2). http://periodicos.puc-campinas.edu.br/seer/index.php/bioikos/article/view/3151

Dafni, A. (1992). Pollination ecology: a practical approach. Oxford University Press.

Ducroquet, J. P. H. J., \& Hickel, E. R. (1991). Fenologia da goiabeira serrana (Feijoa sellowiana, Berg) no Alto Vale do Rio do Peixe, Santa Catarina. Revista Brasileira de Fruticultura, Jaboticabal, 13(3): 313-320.

Eguiarte, L., del Rio, C. M., \& Arita, H. (1987). El nectar y el polen como recursos: el papel ecologico de los visitantes a las flores de Pseudobombax ellipticum (HBK) Dugand. Biotropica, 74-82. https://doi.org/10.2307/2388462

Franzon, R. C., \& Raseira, M. D. C. B. (2006). Germinação in vitro e armazenamento do pólen de Eugenia involucrata DC (Myrtaceae). Revista Brasileira de Fruticultura, 28(1): 18-20. https://doi.org/10.1590/S0100-29452006000100008

Garcês, H. M., Champagne, C. E., Townsley, B. T., Park, S., Malhó, R., Pedroso, M. C., \& Sinha, N. R. (2007). Evolution of asexual reproduction in leaves of the genus Kalanchoë. Proceedings of the National Academy of Sciences, 104(39), 15578-15583. https://doi.org/10.1073/pnas.0704105104

García, C. C. (1998). Kalanchoe spp.: una fuente natural de nuevas sustancias bioactivas puestas de manifiesto por la Etnomedicina. chemistry, 48, 1-29. http://www.encuentros.uma.es/encuentros124/articulos124.pdf

Gonçalves, E. G., \& Lorenzi, H. J. (2007). Morfologia vegetal: organografia e dicionário ilustrado de morfologia das plantas vasculares. Instituto Plantarum de Estudos da Flora. 
Goulson, D. (1999). Foraging strategies of insects for gathering nectar and pollen, and implications for plant ecology and evolution. Perspectives in plant ecology, evolution and systematics, 2(2), 185-209. https://doi.org/10.1078/1433-8319-00070

Herrera, I., \& Nassar, J. M. (2009). Reproductive and recruitment traits as indicators of the invasive potential of Kalanchoe daigremontiana (Crassulaceae) and Stapelia gigantea (Apocynaceae) in a Neotropical arid zone. Journal of Arid Environments, 73(11), 978-986. https://doi.org/10.1016/j.jaridenv.2009.05.004

Junqueira, A. H., \& Peetz, M. D. S. (2014).O setor produtivo de flores e plantas ornamentais do Brasil, no período de 2008 a 2013: atualizações, balanços e perspectivas. Revista Brasileira de Horticultura Ornamental, 20(2): 115-120. https://doi.org/10.14295/rbho.v20i2.727

Karasawa, M. M. G. (2009). Diversidade Reprodutiva de Plantas. Ribeirão Preto, SP: Sociedade Brasileira de Genética - SBG,113 p.

Kearns, C. A., \& Inouye, D. W. (1993). Techniques for pollination biologists. University press of Colorado.

Leon, S. G., Herrera, I., \& Guevara, R. (2016). Mating system, population growth, and management scenario for Kalanchoe pinnata in an invaded seasonally dry tropical forest.Ecology and evolution, 6(13): 4541-4550. https://doi.org/10.1002/ece3.2219

Machado, I. C., \& Lopes, A. V. (1998). A polinização biótica e seus mecanismos na Reserva Ecológica de Dois Irmãos. In: Machado, I. C.; Lopes, A. V. \& Porto, K. C. (Orgs). Reserva Ecológica de Dois Irmãos: Estudos em um remanescente de Mata Atlântica em área urbana (pp.166-187). Editora Universitária da UFPE, Recife, Brasil.

Malerbo-Souza, D. T., \& Silva, F. A. S. (2011). Comportamento forrageiro da abelha africanizada Apismellifera L. no decorrer do ano. ActaScientiarum. Animal Sciences, 33(2): 183-190. https://doi.org/10.4025/actascianimsci.v33i2.9252

Milad, R., El-Ahmady, S., \& Singab, A. N. (2014). Genus Kalanchoe (Crassulaceae): a review of its ethnomedicinal, botanical, chemical and pharmacological properties. European Journal of Medicinal Plants, 86-104. https://doi.org/10.9734 / EJMP /398 2014/5901

Nunes, J. D. O., Dantas, A. D. M., Pedrotti, E. L., Orth, A. I., \& Guerra, M. P. (2001). Germinação de pólen in vitro e receptividade do estigma em macieira cvs. Fuji e Golden Delicious. Revista Brasileira de Fruticultura, 23(1): 35-39.

Oliveira, J.N.B. (1991). "Aspectos pouco comuns da morfologia das plantas superiores", Universidade dos Açores, Ponta Delgada, 176 p.

Parra, V., Vargas, C. F., \& Eguiarte, L. E. (1993). Reproductive biology, pollen and seed dispersal, and neighborhood size in the hummingbird-pollinated Echeveria gibbiflora (Crassulaceae). American Journal of Botany, 80(2): 153-159. https://doi.org/10.1002/j.1537-2197.1993.tb13783.x

Pegoraro, A., \& Neto, A. C. (2005). Disponibilidade de alimento coletado por operárias da abelha africanizada em função dos fatores ambientais. Scientia Agraria, 6(1-2): 35-39. http://dx.doi.org/10.5380/rsa.v6i1.4591

Polatto, L. P., \& Alves Junior, V. V. (2008). Utilização dos recursos florais pelos visitantes em Sparattospermaleucanthum (Vell.) K. Schum.(Bignoniaceae). Neotropical Entomology, 37(4): 389-398. https://doi.org/10.1590/S1519-566X2008000400006

Polatto, L.P., Chaud-Netto, J., \& Alves-Junior, V.V. (2014). Influence of abiotic factors and floral resource availability on daily foraging activity of bees. $J$ Insect Behav 27, 593-612. https://doi.org/10.1007/s10905-014-9452-6

Punt, W., Hoen, P. P., Blackmore, S., Nilsson, S., \& Le Thomas, A. (2007). Glossary of pollen and spore terminology. Review of palaeobotany and palynology, 143(1-2): 1-81. https://doi.org/10.1016/j.revpalbo.2006.06.008

Qaiser, M.; Perveen, A., \& Sarwar, G. R. (2015).Pollen morphology of the family Crassulaceae from Pakistan and Kashmir and its taxonomic implications. Pak. J. Bot, 47(4): 1481-1493. https://doi.org/10.1016/j.revpalbo.2006.06.008

Rashid, M. A., \& Singh, D. P. (2000). A manual on vegetable seed production in Bangladesh. AVRDC-USAID - Bangladesh. Project, Horticulture Research Centre, Bangladesh Agricultural Research Institute.

Rech, A. R., Agostini, K., \& Oliveira, P. E., Machado, I. C. (Eds.). (2014). Biologia da polinização. Projecto Cultural.

Shaw, J. M. H. (2008). An investigation of the cultivated Kalanchoe daigremontiana group, with a checklist of Kalanchoe cultivars.Hanburyana, 3: 17-79. https://www.rhs.org.uk/about-the-rhs/pdfs/publications/hanburyana/vol-3-june-2008/an-investigation-of-the-cultivated-kalanchoe.pdf

Silva, K. N., Dutra, J. C. S., Nucci, M., \& Polatto, L. P. (2013). Influência dos fatores ambientais e da quantidade de néctar na atividade de forrageio de abelhas em flores de Adenocalymmabracteatum (Cham.) DC.(Bignoniaceae). EntomoBrasilis, 6(3), 193-201. https://doi.org/10.12741/ebrasilis.v6i3.295

Smith, G. F. (2020). Taxonomy and nomenclature of Kalanchoex laetivirens (Crassulaceae subfam. Kalanchooideae), a further invasive nothospecies from Madagascar. Phytotaxa, 460(1), 97-109. https://doi.org/10.11646/phytotaxa.460.1.6

Souza, V.C., Flores, T.B., \& Lorenzi, H. (2013). Introdução à Botânica: Morfologia. Nova Odessa, Instituto Plantarum de Estudos da Flora. 223p.

Stanley, R.G., \& Linskens, H.F. (1974). Pollen: biology, biochemistry and management. Springer-Verlag, 172p.

Teixeira, L. V., \& Campos, F. D. N. M. (2005). Início da atividade de vôo em abelhas sem ferrão (Hymenoptera, Apidae): influência do tamanho da abelha e da temperatura ambiente. Revista Brasileira de Zoociências, 7(2). https://periodicos.ufjf.br/index.php/zoociencias/article/view/24161

Van der Pijl, L. (1961). Ecological aspects of flower evolution. II. Zoophilous flower classes. Evolution, 44-59. https://doi.org/10.2307/2405842

Wolff, D. (2006). Nectar sugar composition and volumes of 47 species of Gentianales from a southern Ecuadorian montane forest. Annals of Botany, 97(5): 767-777. https://doi.org/10.1093/aob/mc1033 